\title{
Overview Research on the Text Sorting of Shanhai Jing
}

\author{
Shuyan $\mathrm{Yi}^{1, \mathrm{a}}$ and Fan $\mathrm{Yang}^{1, \mathrm{~b}}$ \\ ${ }^{1}$ College of Humanities \&Sciences of Northeast Normal University, Chang Chun, Jilin, China, \\ 130117 \\ ayishuyan2013@126.com, bivyyangfan@163.com
}

Keywords: Guopu; Shanhai Jing; Text sorting; Literature review; Value.

\begin{abstract}
Shanhai Jing is one of the most important ancient books in the pre- Qin period. Under the condition of the new era, this also has attracted the attention of the academia increasingly. Scholars have studied it from different angles. In the process of studying on Shanhai Jing's relevant text documents, the scholars were more from the following three aspects on the researching of Shanhai Jing: in the first place, the scholars discussed the value of Shanhai Jing form different subject areas; in the second place, some scholars discussed some fundamental researches on the subjects of Shanhai Jing's author, the property, the writing time and the content, in this process, they mainly focus on the angle of the real problems and the fantastic arguments; in the third place, the discussion area is researching on the current situations of Shanhai Jing. By combing the relevant academic achievements, not only can promote the academic understanding of Shanhai Jing in macroscopic aspect, but also can make a clear direction for further detailed interpretation of Shanhai Jing.
\end{abstract}

\section{Introduction}

Since published, Shanhai Jing has always been seen as a controversial book. Generally speaking, the ancients had mixed reviews on Shanhai Jing, The majority of which was denounced. While, under the social and cultural background of modern society, the status of Shanhai Jing has undergone earth-shaking changes, the scholars have become the research focus of Shanhai Jing In many fields. In the past twenty years, On the ShanHai Jing research academic achievements continue to emerge. The following literature review from its main text finishing aspect.

\section{Literature Reviews Researched on the Shanhai Jing's Value from Different Fields}

In ancient dynasties official and private repaired bibliographies, the Shanhai Jing were most classified as the Fubitobe Geography books. That is to say, Shanhai Jing was seen as the reliable history- geography book for a long time. Submit to this relationship, the later scholars always proof the truth of Shanhai Jing from this angle. While the new findings of modern archaeology, ethnology and anthropology provided more evidences to prove that Shanhai Jing is a history-geography book. The modern scholar Mr Wang Guowei first put forward this view. Mr Xuxu developed the idea, he said that Shanjing is one of the oldest geography book in china, which was not a novel said as the scholars in Qing dynasty that who compiled the Siku Quanshu. The contemporary famous historical geography scholar Tan QIxiang thought that the Wuzangshan Jing in Shanhai Jing is a truly geography book and which reflected the truth situation of that time and his this view in the academic circles has profound influence [1] Thus, the historical values of Shanhai Jing was generally accepted by the historians.

Since 90's of the 20th Century, the research Shanhai Jing has entered into a new stage, the papers which affirmmed the value Shanhai Jing from different angles were appearing constantly. There are two main research directions in the searching for Shanhai Jing's values. First, the scholars mainly pay more attention to the noting works of Traditional annotation, and then Judge its nature based on this; the second case is that the scholars focus on the angle of mining the specific Value of Shanhai Jing. The works supported the former view main contained Zhang Butian's the Interpretation of Shanhai Jing (in this book, he considered Shanhai Jing as a geography book[2]), Zhou Mingchu's Shanhai Jing Note, Ma Changyi's the Ancient Map of Shanhai Jing(in this book, he considered Shanhai Jing 
mainly as a myth or witch book[3]) and Liu Zongdi's the Lost bible-- Shanhai Jing and the Ancient China (in this book, he thought the Haijing is a book that reflected in ancient time calendar enveloped figure[4]), etc. The works supported the later view main contained Yitheng Qingsi's the World of Ghosts and Gods in Shanhai Jing, Xu Xianzhi's An Inquiry into Shanhai Jing (in this book, he affirmed Shanhai Jing as a history-geography book[5]), Zhan Yan's Shanhai Jing and the Ancient Society, Ding Zhenzong's Crack Shanhai Jing - China's Ancient X Files[6], etc.

In books that research the specific value Shanhai Jing from different angles, the Japanese scholar Yitheng Qingsi discovered "The Classic of the Great Wilderness" is the value of folklore. Just as what he said in the World of Ghosts and Gods in Shanhai Jing's preface that:" If study its meaning you would find that it really is the rare valuable information to understand aspects of the pre-Qin era of people's lives, and has an important cognitive values. This booklet discussed Shanhai Jing as a special folklore data." "Although it is part of the contents belong to the category of the myth of non-physical, but as the main body which reflected the reality of the world scene." [7] While Xu Xianzhi tried to find out the values that Shanhai Jing contained in the ancient "Fang" "Social" "science and technology in different aspects by using the totem and the modern natural science knowledge. Zhang Yan used the West's "Totem" theory and political power in the form of North American Indian tribes to analyze the combination of Shanhai Jing, trying to discover the "regime of the early stages of the structure of Chinese civilization" which contains. And the modern physics research method was used in the study of Shanhai Jing by the Malaysian Chinese scholars Ding Zhenzong, trying to find out which contains the knowledge of physics.

\section{Literature Reviews Researched on the Basic Problems of Shanhai Jing's Auther, Property, Writing Time and the Content}

In 1995, Hu Yuanpeng published an article called "the Shanhai Jing is a historic book". ${ }^{8]}$ In this paper, He put forward the views as "To Shanhai Jing, what we should do is not revert to ancient myth, but to allow the Shanhai Jing return from myth history, restore the true nature of its historic." The relevant papers as shown in Table 1.

Table 1 The Related works to the overall interpretation of Shanhai Jing

\begin{tabular}{|c|c|c|}
\hline Auther & Paper title & Journal/Years/ Volume Number \\
\hline $\begin{array}{c}\text { Zhuye Zuanpeng } \\
\text { Anongsheng }\end{array}$ & $\begin{array}{c}\text { Research on the non-mythical of } \\
\text { Shanhai Jing }\end{array}$ & $\begin{array}{c}\text { Journal of Huaiyin Teachers College. } \\
\text { No. 4, 1996. }\end{array}$ \\
\hline Zhang Jian & $\begin{array}{c}\text { The Comparative study on } \\
\text { Historical Data of Shanhai Jing } \\
\text { original Social, Mythology? } \\
\text { History? }\end{array}$ & $\begin{array}{c}\text { Chinese Borderland History and } \\
\text { Geography Studies. No. 1, 1996. }\end{array}$ \\
\hline Ouyang Jian & $\begin{array}{c}\text { Seen the origin of the concept of } \\
\text { fantasy From Shanhai Jingo }\end{array}$ & $\begin{array}{c}\text { Journal of Shanghai Normal University } \\
\text { No. 2, 1996. }\end{array}$ \\
\hline Chen Kangzhuan & $\begin{array}{c}\text { Seen the character of Shanhai Jing } \\
\text { form the angle of the hermeneutic }\end{array}$ & $\begin{array}{c}\text { Journal of Human Geography } \\
\text { No. 1 of March, 1997. }\end{array}$ \\
\hline Xu Xianzhi & $\begin{array}{c}\text { Research on the original } \\
\text { appearance and the essence of } \\
\text { Shanhai Jing }\end{array}$ & $\begin{array}{c}\text { Journal of Xi'an Educational College } \\
\text { No. 2, 1998. }\end{array}$ \\
\hline Li Hengmei & $\begin{array}{c}\text { The Absurdity and scientific } \\
\text { explanation of Shanhai Jing }\end{array}$ & $\begin{array}{c}\text { The Journal of Humanities } \\
\text { No. 2, 1998. }\end{array}$ \\
\hline Ye Shuxian & $\begin{array}{c}\text { The Myth, Political and } \\
\text { Geography views of Shanhai Jing }\end{array}$ & $\begin{array}{c}\text { Reviews and Research on Chinese } \\
\text { Literature }\end{array}$ \\
\hline Wo. 3, 1999.
\end{tabular}




\begin{tabular}{|c|c|c|}
\hline & Existential Sentences & Map \\
\hline Wang Hongqi & Shanhai Jing: myth or history? & No. 2000. \\
\hline Luo Zhitian & $\begin{array}{c}\text { Shanhai Jing and modern Chinese } \\
\text { Historiography }\end{array}$ & $\begin{array}{c}\text { Social Sciences In China. } \\
\text { No. 1, 2001. }\end{array}$ \\
\hline Zhan Ziqing & $\begin{array}{c}\text { Shanhai Jing and the History of } \\
\text { Xia Dynasty }\end{array}$ & $\begin{array}{c}\text { Social Science Front. } \\
\text { No. 1, 2003. }\end{array}$ \\
\hline $\begin{array}{c}\text { Wang Naiang, } \\
\text { Cai Wermin }\end{array}$ & $\begin{array}{c}\text { On the Geographical Theory of } \\
\text { Wan and His Contribution to } \\
\text { Wu Zang Shan Jing }\end{array}$ & $\begin{array}{c}\text { Scientia Geographica Sinica. } \\
\text { No. 2 of April, 2003. }\end{array}$ \\
\hline An Jing & $\begin{array}{c}\text { Comparative Studies on Shanhai } \\
\text { Jing and the Wanghui of Yizhou } \\
\text { Book }\end{array}$ & $\begin{array}{c}\text { China's Borderland History and } \\
\text { Geography Studies. } \\
\text { December. 2004. }\end{array}$ \\
\hline Zhang Jian & $\begin{array}{c}\text { Classic of Mountains and Rivers } \\
\text { the Earfiest Annals of } \\
\text { Geography in China }\end{array}$ & $\begin{array}{c}\text { Yueyang Vocational Technical College. } \\
\text { No. 1, 2006. }\end{array}$ \\
\hline
\end{tabular}

In this research field, Ye Shuxian jumpped out of the traditional one-sided finds of thinking Shanhai Jing for the history-geography book and the myth book. Through using the Theory of Sociology knowledge, he introduced the theory of "power politics", thus broke the situation that modern science become a mainstream in Shanhai Jing's research. His point is an inheritance and development to the traditional view of Shanhai Jing "belong to Zhou royal archives". His view will be the traditional the two different argument integrations of "History Book" and "Book Myth" together.

On the basis of recognize Shanhai Jing as a history-geography book, since the beginning of the 20th century, the scholars began to research the scientific elements than Shanhai Jing contains. In 1905, Liu Guanghan pointed out the scientific nature of Shanhai Jing in his paper of Shanhai Jing is not suspicious. Since the 30th of the last century, the scholars began to discuss the Specific scientific value of Shanhai Jing. Since 1980's, the research on the scientific values of Shanhai Jing becomes a hot spot in academia, and the discussion scope mainly involved the aspects of Biology, astronomy, meteorology, climatology, history, archeology, pale anthropology, and musicology, etc. In the $1990 \mathrm{~s}$, $\mathrm{Hu}$ Yuanpeng published the paper as Shanhai Jing is the head of the Science and Civilization in China. This paper discusses the value of Shanhai Jing From astronomy, calendar, geography, history, language, minerals, and medicine, ethnic and other disciplines, etc. Since then, Hu Yuanpeng detailed feasibility studies Shanhai Jing in all areas of its scientific value. Many research works in the 1990's also reflect this characteristic. For example, the Japanese scholar Yitheng Qingsi's "the World of Ghosts and Gods in Shanhai Jing" pay attention to the value of Shanhai Jing's folklore; Ding Zhenzong's "Crack Shanhai Jing- China's Ancient X Files" mainly focus on it's physical value; while Liu Zongdi's "the Lost bible-- Shanhai Jing and the Ancient China" mainly focus on the astronomical calendar value of Shanhai Jing.

Since published, the discussion of the author has always been a research hotspot of Shanhai Jing. Today, although the view as "Shanhai Jing is not a moment, a man, a place of work" has become a contemporary academic circles, but it is still difficult to reach a consensus on the specific territory of the author. People today are discussed in more perspective on the basis of previous extended continue under the new material. Although the specific points vary, but scholars have argued much the same idea, that is start the discussion from the place name of Shanjing, first determine roughly described the mountain by the regional scope of Shanjing, then according the mountains signed in Shanjing to sure the auther's living place. Such as, Liu Zongdi did some comparative study on Shanjing and Guanzi, and then concluded that Shanjing was written by the Jixia scholars. [9] While Jin Quanrong endorsed the former's "Bashu views" [10] Tang Shigui researced from the linguistics and the archeology angles, further proposed that the author of Shanjing was a Chu Shu settlement aristocratic descent. [11] 
The study of edition is a systematic study from the vertical aspect. The related papers are mainly have Jin Rongquan's “The Spread and The Important Ancient Evaluation of Shanhai Jing", Shen Guanghai's "The Brief Spreading of Shanhai Jing" and Ma Changyi's "The Inheritance and Spread of Shanhai Jing Graph", etc.

\section{Literature Review of "Shan Hai Jing" Research Status}

With the deepening of the study on Shanhai Jing's text sorting, the relevant academic achievements are also increasingly rich. In practical terms, the scholars usually in the form of literature review of these academic achievements system, in order to facilitate the future studies. As for the review content, some focus on a research direction, others focus on some scholar's academic achievements. The relevant papers as shown in Table 2 .

Table 2 The Original articles Researched on the Literature Review of Shanhai Jing

\begin{tabular}{|c|c|c|}
\hline Auther & Paper title & Journal/Years/ Volume Number \\
\hline Hu Yuanpeng & Research on the latest trends of Shanhai Jing & $\begin{array}{l}\text { Journal of Guangxi University. } \\
\text { No. } 2,1995\end{array}$ \\
\hline Hu Yuanpeng & $\begin{array}{l}\text { At the present stage of Shanhai Jing's } \\
\text { Research }\end{array}$ & $\begin{array}{l}\text { Journal of Huaiyin Teachers College. } \\
\text { No. 2, } 1997\end{array}$ \\
\hline Zhang Butian & $\begin{array}{l}\text { the Shanhai Jing research review of the 20th } \\
\text { century }\end{array}$ & $\begin{array}{c}\text { Journal of Qinghai Junior Teachers' } \\
\text { College. No. 3, } 1998\end{array}$ \\
\hline Zhang Butian & The early theory of shanhaijing research & $\begin{array}{c}\text { Journal of Yiyang Teachers College. } \\
\text { No. 2, } 1998\end{array}$ \\
\hline Hu Yuanpeng & $\begin{array}{l}\text { Review of theShanhai Jing Study for the last } \\
\text { fifty years }\end{array}$ & $\begin{array}{c}\text { Journal of Wuhan Engineering Institute. } \\
\text { December, } 1999\end{array}$ \\
\hline Zhang Butian & $\begin{array}{l}\text { Review on the Discussion of Shanhai Jing's } \\
\text { geographical scope in 20th century }\end{array}$ & $\begin{array}{c}\text { Journal of Yiyang Teachers College. } \\
\text { No. 1, } 2000\end{array}$ \\
\hline Zhang Butian & $\begin{array}{l}\text { Review on the Discussion of the author and } \\
\text { writing procession of Shanhai Jing in 20th } \\
\text { century }\end{array}$ & $\begin{array}{c}\text { Journal of Yiyang Teachers College } \\
\text { No. 1, } 2001\end{array}$ \\
\hline Zhang Butian & $\begin{array}{l}\text { Review on the character of Shanhai Jing in } \\
\text { 20th century }\end{array}$ & $\begin{array}{l}\text { Journal of Yiyang Teachers College } \\
\text { No. 5, } 2000\end{array}$ \\
\hline $\begin{array}{l}\text { Zhang } \\
\text { Guoping }\end{array}$ & An overview of the Shanhai Jing Research & $\begin{array}{l}\text { The Silk Road } \\
\text { No. } 20,2009\end{array}$ \\
\hline Jin Quanrong & $\begin{array}{l}\text { General comment on Shan Hai Jing study in } \\
\text { the past } 2000 \text { Years }\end{array}$ & $\begin{array}{l}\text { Journal of Yiyang Teachers College. } \\
2000,20(4)\end{array}$ \\
\hline Zhang Jinfu & $\begin{array}{c}\text { An overview of the Gong Yuhai's Shanhai } \\
\text { Jing Research }\end{array}$ & $\begin{array}{l}\text { China Place Name } \\
\text { No. 4, } 2004 \\
\end{array}$ \\
\hline Hu Yuanpeng & Briefly describes the shanhaijing research & $\begin{array}{c}\text { Journal of Fuqing Branch of Fujian Normal } \\
\text { University. No. 3, } 2006\end{array}$ \\
\hline Zhang Butian & $\begin{array}{l}\text { Briefly describes the ancient shanhaijing } \\
\text { research }\end{array}$ & $\begin{array}{c}\text { Journal of Fuqing Branch of Fujian Normal } \\
\text { University. No. 1, } 2008\end{array}$ \\
\hline Ge Lan & Zhong Jingwen, Museum and Shanhai Jing & $\begin{array}{c}\text { China Book Review } \\
\text { No. } 9,2007\end{array}$ \\
\hline Sun Yuzhen & Review of the Shanhai Jing Research & $\begin{array}{c}\text { Journal of Shandong University of } \\
\text { Technology } \\
\text { No. } 1,2003\end{array}$ \\
\hline $\begin{array}{l}\text { Tang Qicui } \\
\text { Hu Taoxiong }\end{array}$ & $\begin{array}{c}\text { Review of Ye Shuxian's Shanhai Jing } \\
\text { Research }\end{array}$ & $\begin{array}{c}\text { Journal of Yangtze University } \\
\text { No. 2, } 2006\end{array}$ \\
\hline
\end{tabular}




\section{Conclusion}

Through summarized on the papers above from different angles, you can find that the related researchs are mostly focused on the peripherals of Shanhai Jing. By sorting out the academic achievements of these fields, could promote the academic macro understanding of Shanhai Jing, So as to make a guidelines clearer direction in further interpreting Shanhai Jing.

\section{Acknowledgements}

The paper was funded by the project of Social Science Foundation of Jilin Province (NO. 2016BS48) and the project of Jilin Province Department of Education Fund (NO.2014B056), belongs to their initial results.

\section{References}

[1] Q.X. Tan: The geographic scope of an five hidden mountain. New Probe of Shanhai Jing (Sichuan academy of social sciences press, Chinese 1986). p. 13.

[2] B.T. Zhang: The understanding of Shan Hai Jing (Tianma book publishing co., LTD, Hongkong, China, 2004.). p. 125.

[3] C.Y. Ma: The Ancient Map of Shanhai Jing (Shandong Pictorial Publishing House, Chinese 2001). p. 405.

[4] Z.D. Liu: Lost a sealed book < seas > and ancient Chinese world (the Commercial, Chinese 2010). p. 159.

[5] X.Z. Xu: Exploration of Shanhai Jing (Wuhan Press. Chinese 1991). p. 162.

[6] [Malaysia] Z.Z. Ding: Crack Shanhai Jing- China's Ancient X Files. (Zhongzhou Ancient Books Publishing House. Chinese 2001). p.232.

[7] [Japan] Q.S. Yiteng: World of Ghosts and Gods in Shanhai Jing (China folk literature and art publishing house, Chinese 1990) . p.102.

[8] Y.P. Hu: The Disscusion of Shanhai Jing is a Historic Book. Chinese Culture Research, (1999) No.4, p.46.

[9] Z.D.Liu: Discussion on the Thesis of Shanjing was written by the Jixia Scholars, Folklore Studies (2003) No.2, p.95.

[10]Q.R. Jin: The Author of Shanhai Jing Should be a Bashu Person. Guizhou Social Sciences Magazines. VOL.192 (2004) No.6, p.64.

[11] S.G. Tang and X.M. Tang: Shan Hai Jing the Chinese Text Author Questions ( II ). Journal of Panzhihua University. (2008) No.4, p.35. 